\title{
MINIMUM WAGES, LABOR MARKET INSTITUTIONS, AND YOUTH EMPLOYMENT: A CROSS-NATIONAL ANALYSIS
}

\author{
David Neumark and William Wascher*
}

March 2003

\footnotetext{
*Neumark is Senior Fellow, Public Policy Institute of California, Professor of Economics at Michigan State University, and Research Associate of the NBER. Wascher is Assistant Director in the Division of Research and Statistics at the Board of Governors of the Federal Reserve System. The initial work on this paper was done while Wascher was a visiting economist at the Bank for International Settlements. We are grateful to Norm Bowers, Daniel Hansen, Mark Keese, Stephen Machin, and Alan Manning for help in obtaining the data, and to Palle Andersen, Linda Bell, and Daniel Hamermesh for helpful comments. The views expressed are those of the authors only, and do not necessarily reflect those of the Federal Reserve Board, the Bank for International Settlements, or the Public Policy Institute of California.
} 


\title{
MINIMUM WAGES, LABOR MARKET INSTITUTIONS, AND YOUTH EMPLOYMENT: A CROSS-NATIONAL ANALYSIS
}

\begin{abstract}
$\underline{\text { Abstract }}$
We estimate the employment effects of changes in national minimum wages using a pooled crosssection time-series data set comprising 17 OECD countries for the period 1975-2000, focusing on the impact of cross-country differences in minimum wage systems and in other labor market institutions and policies that may either offset or amplify the effects of minimum wages. The average minimum wage effects we estimate using this sample are consistent with the view that minimum wages cause employment losses among youths. However, the evidence also suggests that the employment effects of minimum wages vary considerably across countries. In particular, disemployment effects of minimum wages appear to be smaller in countries that have subminimum wage provisions for youths. Regarding other labor market policies and institutions, we find that more restrictive labor standards and higher union coverage strengthen the disemployment effects of minimum wages, while employment protection laws and active labor market policies designed to bring unemployed individuals into the work force help to offset these effects. Overall, the disemployment effects of minimum wages are strongest in the countries with the least regulated labor markets.
\end{abstract}

Keywords: Minimum wages, youth employment

JEL classification: J23, J38 


\section{Introduction}

A distinguishing characteristic of the "new minimum wage research" of recent years has been a shift away from a reliance on time-series variation in minimum wages toward the use of cross-section or panel data to identify the employment effects of minimum wage laws. In earlier decades, the time-series approach dominated research on minimum wages in the U.S. and was instrumental in shaping economists' views of the economic implications of minimum wages. After a number of U.S. states raised their minimum wage levels above the national minimum, however, researchers began to examine the employment differences associated with this regional variation in wage floors. The shift toward the use of cross-section data was motivated by the recognition that there are important limitations to relying solely on the time-series evidence on minimum wage effects - namely that there have been relatively few legislated minimum wage changes for the U.S. as a whole, and that changes in the federal minimum wage often coincided with other events, such as recessions, that were also likely to affect youth employment.

Another potential advantage of using cross-section or panel data to study minimum wage effects is that such data may provide potentially valuable information on how the effects of minimum wages interact with other labor market policies that may or may not be directly associated with the minimum wage.

Evidence on the value of youth subminimum wage laws in reducing the disemployment effects of minimum wages is one area that has been addressed using panel data (Neumark and Wascher, 1992). But it is not difficult to think of other labor market policies or institutions that might exacerbate or reduce minimum wage effects, including policies not formally related to the minimum wage.

In this paper, we attempt to address empirically the question of how other labor market policies and institutions influence the effects of minimum wages by exploiting cross-national variation in the minimum wage. In particular, we estimate the effects of minimum wages on youth employment rates using a pooled cross-section time-series data set comprising 17 OECD countries for the period 1975-2000. The countries in our study have strikingly different patterns of minimum wage changes over time, which helps to separate the influences of minimum wages from other macroeconomic events affecting employment in multiple countries. In addition, the level of the minimum wage differs considerably across countries, with wage floors substantially higher in many European countries than in North America; this difference is often asserted to be one reason for the high rates of structural unemployment in Europe. Most importantly for our study, we have supplemented the country-level data on employment and minimum wages with information on cross-country differences in minimum wage systems and on other labor market institutions and policies. Our study is thus in the spirit suggested by Hamermesh (2002), who argues that minimum wage research is an area in which international data are particularly valuable, so long as one takes into account the international variation in labor market policies or institutions that might affect estimates relying on crosscountry variation in minimum wages. 


\section{Previous Estimates of Minimum Wage Effects Using International Data}

As indicated above, much of the new minimum wage research has attempted to exploit the additional cross-sectional variation in the U.S. produced by the increases in state-specific minimum wage rates in the late 1980s and early 1990s. The specific consequences of this approach for estimates of employment elasticities are summarized in Card and Krueger (1995) and in Neumark and Wascher (1996). However, the bottom line is that this new strain of research led to a substantially wider range of elasticity estimates than was reported in the earlier time-series literature, prompting some economists to question the consensus view that minimum wages reduce employment among lower-skilled workers.

Following on the results for the U.S., there also has been a renewed interest in reassessing the effects of minimum wages in European (and other) countries. This interest undoubtedly stems to some extent from the challenge presented to the conventional wisdom in the U.S. by the wider range of estimates reported in the recent literature. But, in addition, the increasing integration of European labor markets associated with the expansion of the European Community and, more recently, the European Monetary Union, has drawn attention to the potential impact of differing degrees of labor market rigidity across countries - the minimum wage being one possible source of such rigidity - in the context of increasing factor mobility and a unified monetary policy.

As in the U.S., the results reported for individual European countries differ considerably across studies. The variability in reported results is probably most striking for France, where it is often argued that high minimum wage levels are the main cause of high unemployment rates among youths. For example, Bazen and Skourias (1997) conclude that the large increase in the minimum wage in France in 1981 (and subsequent smaller increases) reduced youth employment rates in the early 1980s. Similarly, Abowd, et al. (1997), using longitudinal data, find negative effects on youth employment probabilities from real minimum wage increases in France (and in the U.S.) during the 1980s. However, Dolado, et al. (1996) and Machin and Manning (1997), who use regional variation in average wages to identify minimum wage effects, find little evidence of a negative impact on employment from the wage floor during that period. Among other industrialized countries (including some outside of Europe) for which researchers have attempted to estimate the effects of minimum wages on employment, differing results are also evident in studies of the U.K. (see, for example, Minford and Ashton (1996) vs. Machin and Manning (1994, 1996)), the Netherlands (Van Soest (1994) vs. Dolado, et al. (1996)), New Zealand (Maloney (1995) vs. Mare (1995) and Chapple (1997)), and Portgual (Pereira (forthcoming) vs. Portugal and Cardoso (2002)). In 
contrast, consistently negative employment effects have been reported for Canada (e.g., Baker, et al. (1999)) and Spain (Dolado, et al. (1996); Dolado, et al. (1997)). ${ }^{1}$

Surprisingly, there have been few studies that use the variation in minimum wages and employment rates across countries to estimate minimum wage effects, which is the methodology we adopt in this paper. Indeed, the only one of which we know is a recent OECD study (1998), which estimates pooled time-series cross-section regressions for a set of seven OECD countries. The results in that study show negative and statistically significant minimum wage effects on the employment rates of teenagers across a variety of specifications. The authors also report consistently negative point estimates of the minimum wage employment elasticity for 20-24 year-olds, although these tend not to be statistically significant. Although these results are based on the experience of a fairly limited set of countries, the OECD study tentatively concludes from this evidence that minimum wages have a "negative effect on teenage employment" (p. 47).

There is, however, a growing body of literature that uses cross-country comparisons to investigate labor market policies more generally. Perhaps the most widely known are the studies that examine the effect of job security regulations on employment and unemployment (e.g., Lazear (1990), OECD (1999) and Di Tella and MacCulloch (1999)); some of these studies have tended to find a negative impact of these regulations on labor markets, while others report little or no effect. In addition, broader studies of labor market rigidities and unemployment have been published by Nickell (1997), Siebert (1997), and Blanchard and Wolfers (2000), again with varying conclusions. ${ }^{2}$

Critics of the cross-country approach to studying the effects of labor market policies on employment outcomes point to concerns about the ability to separate the impact of specific labor market policies on employment from the consequences of other economic shocks or policies, as well as to concerns that policy differences across countries interact in ways that make inferring the effect of any particular policy problematic. We attempt to address these concerns in several ways. First, we employ the ratio of the minimum wage to the average wage as our minimum wage variable; this form of the variable mitigates potential biases arising from a correlation between the minimum wage and economic events that affect wage levels more generally. Of course, specifying the minimum wage variable in this way potentially leads to a bias associated with a correlation between overall wage levels and economic conditions, and thus we focus on specifications that include fixed country effects, which should mitigate biases stemming from persistent differences in employment and wages that are associated with long-standing characteristics of a country's labor market (other than the minimum wage); we also include the adult unemployment rate as a control for general labor market conditions in each country. Third, we include country-specific time trends

\footnotetext{
${ }^{1}$ The age groups vary slightly in these studies, but generally cover some subset of workers between the ages of 15 and 24 .
} 
in most specifications in order to control for incremental changes in employment rates associated with longer-term developments in labor force participation or labor demand that are unrelated to changes in a country's minimum wage laws. Finally, we estimate empirical specifications that permit the effect of minimum wages to differ with the types of policies and institutions present in each country. Such specifications are informative about how minimum wages interact with other labor market policies and institutions that vary across countries.

III. Data

The data we use in this study are drawn primarily from two sources. The majority of data on population, unemployment rates, and employment rates are taken from OECD published sources, including Labour Force Statistics and the annual Employment Outlook reports. In particular, we use information on employment and unemployment rates for youths, the unemployment rate for prime-age adults (as a business cycle control), and the relative cohort size of the youth population (as a supply-side control) for each country in our sample. For most countries, the overall youth age group is defined as ages 15 through 24 (or for teenagers, 15 to 19); the exceptions are Italy, where this population begins at age 14, and the U.S., the U.K., Norway, Spain, and Sweden, where the relevant age groups start at age 16. The prime-age adult age group refers to individuals aged 25 to 54 in most countries; the only exception is Italy, where the relevant age group is 25 to 59. For simplicity, we refer to the 15-24 year-olds as "youths," the 15-19 year-olds as "teenagers," and the 25-54 year-olds as "adults."

Data on minimum wages are available from the OECD for countries where a national minimum wage is set by statute or by national collective bargaining agreement. ${ }^{3}$ For countries where no national minimum exists, but where industry- or occupation-specific minimums are set by legislation or collective bargaining agreements, we use summary estimates constructed by Dolado, et al. (1996). In all cases, the minimum wage measure is defined as the ratio of the nominal value of the minimum wage to an average wage. ${ }^{4}$ This is one of the standard indicators used in the literature on minimum wages and is intended to measure the extent to which the minimum wage cuts into the wage distribution, and to capture variation in the relative prices of less-skilled and more-skilled labor induced by minimum wages. In addition, even in countries for which there is a national minimum wage level, that level is sometimes superceded by specific laws applicable to workers in particular geographic regions or industries or by federal-level exclusions that apply to specific types of workers. We collected this information from various OECD reports, the European

\footnotetext{
${ }^{2}$ For an analysis of the role of cross-country variation in labor market policies and institutions in a different context, see Blau and Kahn's (1996) research on differences in wage distributions across countries.

${ }^{3}$ These countries include Australia, Belgium, Canada, France, Greece, Japan, Luxembourg, the Netherlands, New Zealand, Portugal, Spain, and the U.S. Following recent enactment of new national minimum wage legislation in Ireland and the U.K., the OECD has also begun to report minimum wage levels for these countries.
} 
Commission (1998), the U.K. Low Pay Commission Report (2001), and the U.S. Department of State (2001). Key characteristics of minimum wage laws in each country are described in more detail in the appendix.

Finally, we also have gathered some information on other labor market policies in effect in OECD countries. Much of this information is cross-sectional and refers to policies in effect in the late 1980s or early 1990s. For example, we use three indicators of such policies assembled by the $\operatorname{OECD}(1994,1996)$. The first is an indicator of labor standards in existence in 1993. This measure is constructed as the sum of the OECD's assessment of the stringency of regulations in three areas: working time, fixed-term contracts, and employees' representation rights. ${ }^{5}$ The second indicator, which refers to 1989 , is derived from rankings of the strength of the legal system regulating hiring and firing. The third indicator is a measure of the extent to which countries use active labor market policies to promote employment. This measure is defined as the percent of GDP spent by the public sector in 1995 on three types of labor market programs: public employment services, labor market training, and employment subsidies. In addition, we use two variables for which time-series observations are available: a measure of the gross benefit replacement rate for unemployment insurance developed by the OECD and estimates of union density calculated by Nickell and Nunziata (2001).

In general, our sample is limited to those countries for which the OECD publishes time-series data on labor market activity for most or all of the period dating back to the mid-1970s and for which we could obtain information on minimum wages. For recent years, we have data on the 20 major industrialized countries listed in Table 1. However, we were unable to obtain a sufficient time-series history of minimum wages for Finland, Ireland, and Norway, and so these countries are dropped from much of the analysis. IV. Empirical Analysis

Although we do not present an explicit theoretical model in this paper, our empirical analysis can be viewed as a test of the model of policy complementarities in the labor market developed by Coe and Snower (1997). In this model, policies or institutions that influence the search behavior of the unemployed, barriers to job creation, and the bargaining power of workers and employers can have complementary effects on unemployment such that the effects of enacting of a job-reducing policy could be magnified or reduced depending on the restrictiveness of the existing labor market environment. Coe and Snower present an example in which the effects of the minimum wage on unemployment are influenced by job security legislation, unemployment benefits, job creation measures, and policies influencing the bargaining

\footnotetext{
${ }^{4}$ In the case of OECD data, the average wage is a median wage. Dolado, et al. use a mean wage in constructing their indices.

${ }^{5}$ The OECD also includes indicators of the bite of minimum wages and employment protection in the summary index. However, because of our interest in estimating the effects of these policies directly, we dropped those components and recalculated the index.
} 
power of incumbent workers. Most notably, in their model, stricter job security measures, more generous unemployment benefits, and greater bargaining strength for incumbent employees tend to exacerbate the negative employment effects from an increase in the minimum wage, while policies designed to increase rates of job creation tend to mitigate those effects.

\section{Preliminary Data Analysis}

The first two columns of Table 1 display the minimum wage ratios in 1976 and 2000, ordered by the relative value of the wage floor in $2000 .^{6}$ As can be seen in the second column, there is substantial variation in the bite of minimum wages across countries, with the level of the minimum ranging from more than 70 percent of the average wage in Italy to only 32 percent in Spain. As is often noted, the higher minimum wage levels are almost universally found in continental Europe. Indeed, Australia is the only non-European country with a minimum wage ratio above 50 percent in 2000. In contrast, the other Anglo countries and Japan are towards the bottom of the distribution, with minimum wage ratios typically at about 45 percent or below in 2000 .

A comparison of the first and second columns also indicates that some countries have experienced substantial changes in relative minimum wages over the past 25 years, which, in most cases, have reduced the level of the minimum wage relative to an average wage. Of the 17 countries for which figures are available in both years, 14 experienced a reduction in the minimum wage ratio over that period, and only Luxembourg saw a meaningful increase in the minimum wage. Particularly notable are the declines for the Netherlands, where the government implemented a cut in the nominal minimum wage in 1984 (and a freeze through the remainder of the 1980s), and for some Southern European countries (Greece and Spain), where nominal minimum wage increases significantly lagged behind the overall pace of wage growth. In addition, the U.K. abolished its system of Wage Councils in August 1993 and did not introduce a national minimum wage until April 1999. Thus, although the entry for the U.K. in the second column of Table 1 refers to the minimum wage ratio in 2000, only data for the U.K. through 1992 are included in the analysis. ${ }^{7}$

The remaining columns of the table summarize some other characteristics of minimum wage provisions in these countries as of the early 1990s. In particular, the third column shows how minimum wages are determined in each country, while the fourth column indicates the level of disaggregation in the process. Except for France and Australia, the countries with relatively high minimum wage ratios are those

\footnotetext{
${ }^{6}$ Where information was not available for 2000 , we have indicated in parentheses the year for which we report this ratio.

${ }^{7}$ We excluded the U.K. observations with values of zero for the minimum wage for two reasons. First, the implied minimum wage change would be very large relative to the other minimum wage variation in our sample, and thus the employment changes in this single episode would tend to have an inordinate effect on the overall coefficient estimate. Second, and more important, even when the minimum wage is eliminated, there is surely a floor well above zero (e.g., the value of leisure) below which wages would not fall, implying that using a zero value for the minimum wage for these observations could result in a gross misspecification of the model.
} 
that tend to allow unions to play an active role in negotiating the appropriate level of minimum wages, while the countries with low ratios tend to be those where the wage floor is set by statute. In addition, there are differences in the extent to which minimum wage levels vary across industries or geographic regions, particularly in those countries where the wage floor is determined through the collective bargaining process.

The last column of the table displays information on the existence of a minimum wage level for youths that is below the level applied to adults. Most countries have some form of youth subminimum, although it often is quite limited in terms of age or is applicable only for youths with short tenure. Because we were unable to compile sufficient time-series information to construct minimum wage ratios explicitly for youths, the ratios we use in our subsequent analysis are measured as the adult minimum relative to an average wage for the entire working population. This procedure may introduce some error into our wage ratio for some countries, an issue to which we will return later in the paper when we incorporate information on youth subminimum provisions into our analysis.

In Table 2, we report the information for minimum wage ratios in 1986 and 2000, along with data on employment-to-population ratios and unemployment rates for 15-24 year-olds. It is difficult to see an unambiguous pattern in the cross-section data. In some countries with high minimum wage ratios (e.g., Italy and France), youth labor market conditions appear to be relatively poor, while in others (e.g., Germany and Denmark), employment rates look relatively high and unemployment rates low. Similarly, among those countries with low minimum wage ratios, there are countries with favorable youth labor market conditions (e.g., the U.S.) and those with poor youth labor market conditions (e.g., Spain). Nevertheless, as shown in the second to last row, there is a negative correlation between the minimum wage ratio and the youth employment-to-population ratio in both 1986 and 2000, and a small positive correlation between the minimum wage ratio and the youth unemployment rate in each year. ${ }^{8}$ In addition, as can be seen in the last row of Table 2, the raw correlation between the change in minimum wages and the change in employment rates between 1986 and 2000 is -0.46 (and statistically significant at the $10 \%$ level), while the correlation between changes in minimum wages and changes in unemployment rates is 0.50 (and statistically significant at the $5 \%$ level).

\section{Basic Regression Results}

The correlations shown in Table 2 are intended only to be descriptive. Minimum wages obviously were not the only factor affecting youth labor markets over this period, and in Table 3, we extend the

\footnotetext{
${ }^{8}$ As has often been noted, the predictions of various economic theories about the labor market effects of minimum wages pertain more to employment than to unemployment, because of the ambiguous effects of labor force participation decisions on the latter. This is particularly true in the case of youths, for whom unemployment and nonparticipation in the labor force are typically not distinct states. Thus, in the remainder of the paper, we focus our analysis on the implications of minimum wages for employment-to-population ratios and drop references to youth or teenage unemployment rates.
} 
analysis to control for the influence of events that affect labor markets more generally, including business cycle movements, demographic changes, and other government policies. We implement this procedure in a panel-data regression context, relating the minimum wage to youth employment rates using data pooled across both countries and years. In addition to the adult unemployment rate, which is included to control for aggregate economic conditions, we introduce as a supply-side control the ratio of the youth population to the adult population (referred to as relative cohort size in the table).

The model we estimate is of the form:

$$
E_{i t}=\alpha_{i}+\lambda_{t}+\delta_{i} t+\beta M W_{i t}+X_{i t} \Gamma+v_{i t}, \quad i=1, \ldots, I ; t=1, \ldots, T_{i} .
$$

In this specification, $\mathrm{E}_{\mathrm{it}}$ is the employment-to-population ratio for youths, $\mathrm{MW}_{\mathrm{it}}$ is the ratio of the minimum wage to the average wage, and the vector $X_{i t}$ includes the unemployment rate for adults and the relative size of the youth cohort; $i$ indexes countries and $t$ indexes years. In addition, in some specifications we include fixed country effects $\left(\alpha_{i}\right)$, year effects $\left(\lambda_{t}\right)$, separate time trend variables for each country $\left(\delta_{i} t\right)$, and/or a lagged dependent variable. The sample period for the regression is 1976 to 2000 where possible; countries for which we had to use shorter samples are listed in the notes to the table.

In previous studies of the U.S. and Canada, the evidence suggested that the employment effects of minimum wages take at least a year to be fully reflected in the data, presumably because of the time it takes employers to adjust factor inputs to changes in factor prices (Neumark and Wascher, 1992; Baker, et al., 1999). One might think that this adjustment process would be even slower in European countries, where legal restrictions on dismissals are generally stricter than in the U.S. Reflecting these considerations, we use one lag of the minimum wage ratio in the results presented in the tables. This specification - together with the inclusion of fixed effects - also has the advantage of reducing the potential endogeneity of the minimum wage variable arising from correlations of either the minimum wage or the average wage with overall labor market conditions or productivity. ${ }^{9}$

Panel A of Table 3 presents results for the 15-24 year-old age group. The first column of the table reports estimates for specifications that exclude fixed country effects, year effects, and country-specific time trends. In general, these results tend to confirm the negative simple correlation between minimum wages and youth employment rates reported in Table 2. The coefficient on the minimum wage variable is negative and statistically significant, and the estimated elasticity (shown in the bottom row of the panel and evaluated at sample means) is -0.22 , in the general range of the elasticities often reported for the U.S. In addition, the adult unemployment rate has a strong negative relationship with youth employment rates, with

\footnotetext{
${ }^{9}$ The results were qualitatively similar in specifications that used the contemporaneous minimum wage ratio or both the contemporaneous and lagged minimum wage ratio, as well as when we also included lags of the adult unemployment rate and the relative cohort size variable.
} 
the size of the coefficient suggesting that changes in general labor market conditions are amplified in the labor market for young workers. The coefficient on the relative size of the youth cohort in column (1) indicates a positive effect of that variable on youth employment rates, in contrast to the negative effect that would be predicted in this reduced-form specification (and which occurs in later specifications) if the greater supply of youths resulted in lower wages for lower-skilled workers. ${ }^{10}$

In column (2) of the table, we add in fixed country effects to capture other persistent country-specific factors that may influence youth employment rates independently of general labor market conditions (as captured in the adult unemployment rate). Examples of such factors might include government policiessuch as youth employment programs - as well as cultural or other institutional differences across countries that lead to cross-sectional variation in the propensity of youths to work. A drawback of introducing fixed country effects is that they eliminate some of the cross-sectional variation in minimum wages that helps to identify the effects of wage floors on employment. However, Table 2 clearly indicates that there are some large differences in employment rates across countries that seem unrelated to differences in minimum wage levels, and Hausman/Sargan tests strongly reject the hypothesis that the fixed country effects can be omitted from the specification. As can be seen in column (2), adding in the fixed country effects reduces the size of the estimated minimum wage effect to -0.14 , as well as its statistical significance; the estimated elasticity in this case is -0.15 .

Columns (3) and (4) add in year effects and country-specific time trends, respectively. Year effects control for global shocks or policies that might influence youth employment rates in all countries, while country-specific trends are intended to capture factors that might influence employment trends within a country. Both of these additional sets of controls tend to make the coefficient on the minimum wage ratio more negative, and in both cases the Hausman/Sargan test rejects omitting them from the specification. ${ }^{11}$ Thus, in column (5), we report estimates from a specification that includes all three sets of controls (country effects, year effects, and country-specific time trends). In this specification, the coefficient on the minimum wage ratio drops back to -0.15 , with an estimated elasticity of -0.16 . We continue to include the full set of controls in most of the analysis that follows, although we would note that such a specification is unfortunately vague about the origin of cross-section variation in the data and so may be too stringent. Nonetheless, it is encouraging that these baseline estimates do not appear to be especially sensitive to the inclusion or exclusion of the various controls.

As a final specification check, we estimate a dynamic version of the model shown in column (5) by including the lagged youth employment rate in the model. In such a specification, the inclusion of the

\footnotetext{
${ }^{10}$ See Korenman and Neumark (2000) for an analysis of cohort size effects using data for OECD countries.

${ }^{11}$ These tests also reject omitting year effects or time trends in the presence of the other set of controls.
} 
lagged dependent variable can be thought of as incorporating a sluggish response of employment to changes in the fundamental determinants of labor demand or as helping to account for omitted variables that evolve slowly and are not already captured by the other control variables in the model. Nickell (1981) has shown that including the lagged employment rate introduces a bias in standard panel estimation techniques. Although the length of our panel (up to 25 years) suggests that the size of this bias may be relatively small, we nonetheless employ the Generalized Method of Moments (GMM) technique developed by Arellano and Bond (1991) to estimate the dynamic model. As shown in column (6), the estimated minimum wage elasticity from this specification falls slightly to -0.13 , but remains statistically significant. ${ }^{12}$

Panel B of the table presents results obtained when we restrict the population under consideration to teenagers aged 15 to 19 . It is often argued that employment effects should be larger for teenagers because this group includes a higher concentration of workers whose market wage would be below the legislated minimum wage. On the other hand, theoretical implications and empirical results for teenagers may be more ambiguous because of interactions between minimum wages, employment, and schooling (Neumark and Wascher, 1996). As can be seen in columns (1)-(3), the disemployment elasticities are slightly smaller for teenagers than for the youth population as a whole in the specifications that exclude country-specific time trends. When the country-specific trends (and other controls) are included, however, the estimated elasticity for teenagers rises to around -0.25 , about $1 / 3$ higher than for the $15-24$ year old population. ${ }^{13}$ Similarly, in the dynamic version of the model, the estimated elasticity for teenagers $(-0.18)$ is somewhat larger than for the youth group as a whole.

In cross-country studies, it is difficult to completely account for country-specific characteristics that might complicate the interpretation of the parameters of interest. With that caveat, our sense is that, on balance, the results from the basic specification and its variants provide support for the view that, on average, minimum wages tend to reduce youth employment in the 17 countries we analyze. ${ }^{14}$ In the following sections, we examine whether other aspects of minimum wage systems in each country or the presence of other labor market policies or institutions influence the employment effects of the minimum wage.

\footnotetext{
${ }^{12}$ The inclusion of the lagged employment rate can also be interpreted as helping to distinguish between the short-run and long-run effects of the minimum wage on employment. Representing the coefficient on the lagged dependent variable as $\rho(=0.42), \beta=-0.12$ is the short-run coefficient under such an interpretation, while the long-run coefficient is calculated as $(\beta /(1-\rho))=-0.21$.

${ }_{14}^{13}$ Again, Hausman/Sargan tests reject the omission of the controls.

${ }^{14}$ In a similar cross-country study focusing on the impact of unions on youth employment rates, Kahn (2000) finds that a more pronounced union presence is associated with higher relative wages and lower employment rates for youths. Taken together, the results in our paper and in Kahn suggest that imposed higher wage floors are detrimental to youth labor market performance.
} 


\section{The Sensitivity of the Estimates to Other Characteristics of Minimum Wage Systems}

As indicated in Table 1, there are differences in minimum wage systems across countries that extend beyond the wage floor itself. We have singled out three particular areas where minimum wage policies might be expected to influence the employment effects of a wage floor. The first of these is the process by which minimum wages are determined. In some countries minimum wage levels are set by statute, while in other countries they are the product of a collective bargaining process, with unions, employers, and the government all participating in the negotiations. ${ }^{15}$ It seems possible that the method used to set minimum wages might influence the extent to which a wage floor affects labor markets, although the direction of this influence is not obvious. For example, if unions and employers have a better sense of what constitutes a relevant market wage for unskilled labor and use that information in deciding on the appropriate level of the minimum wage, taking account of potential adverse employment effects, then one might expect the minimum wage to have a weaker distortionary effect on the labor market. In contrast, if the presence of unions in the negotiating process simply results in a higher minimum wage than would otherwise be set (say, for example, because unions view a higher minimum as raising the demand for their more-skilled members), then countries using a collective bargaining approach might see greater disemployment effects than countries with legislated minimums.

Second, minimum wage policies differ across countries in the extent to which wage floors vary across regions or industries. ${ }^{16}$ Such variation might also influence the impact of minimum wages on labor markets, although the direction of the effect could again be in either direction. On the one hand, regional or industry variation in minimum wages implies greater flexibility in the process, which could be used to set more appropriate minimum wage levels for specific subgroups of workers. If the alternative were a national minimum wage that was appropriate in only a few cases (i.e., industries or regions) and too high in most others, this added flexibility would reduce any disemployment effects. If, however, the alternative was a low national minimum wage, or if the variation represented a tendency for some regions or industries to set high minimum wage levels regardless of the relative productivity of the applicable subgroup, then the added dispersion might be associated with a greater bite from minimum wages than indicated by our national measure.

\footnotetext{
${ }^{15}$ The U.K., where minimum wages were set by Wage Councils prior to 1993, is included in the group of countries using a collective bargaining approach. As indicated in Dolado, et al. (1996), the Wage Councils "consisted of an equal number of employer and worker representatives, plus a maximum of three independent members (nominated by the government of the day) who had the casting vote if an agreement was not reached" (p. 353).

${ }^{16}$ Some judgment was necessary to classify the countries into two distinct groups; see Table 1 for our classification. As significant regional variation in the U.S. exists only in the second half of our sample, we also used a classification in which we coded the U.S. as having a national minimum wage. This change had little effect on the results.
} 
Third, countries differ in the degree to which the minimum wage for youths is lower than that for adult workers. ${ }^{17}$ In contrast to the other characteristics we consider, the presence of a youth subminimum should unambiguously reduce the disemployment effect of the minimum wage as we measure it. As we noted earlier, constraints on the availability of data have led us to use an adult minimum wage, despite our focus on the youth labor market. Thus, for countries in which a youth subminimum is important, we have potentially overstated the extent to which the minimum cuts into the wage distribution. Moreover, if a youth subminimum leads employers to substitute youths for low-skilled adults, any negative impacts of raising the national minimum might be even more difficult to distinguish because of a potentially offsetting positive impact on youth employment. ${ }^{18}$

In Table 4, we attempt to assess the importance of these institutional differences in minimum wage systems by permitting the coefficient on the minimum wage variable to differ with these three characteristics of minimum wage setting. These estimates are based on the same specifications as in Table 3 , in that they include the adult unemployment rate, the relative cohort size variable, and some set of additional controls. As a starting point, the specifications shown in the first column for each age group ((1) and (4)) exclude country fixed effects, but allow the average employment rate (conditional on the other controls) to vary across the three classifications by adding dummy variables for the features of minimum wage systems. This allows us to estimate whether these features of minimum wage systems are associated with differences in average employment rates across countries and to test whether the inclusion of these additional characteristics of country-specific minimum wage laws obviates the need to include the fixed country effects. ${ }^{19}$ In these specifications, the coefficient estimates show that countries with subnational minimum wage levels and youth subminimums tend to have higher employment rates than do other countries; in contrast, there is no statistically significant difference in average employment rates in countries distinguished by the process used to set the minimum wage (statute vs. collectively bargained). The effect of the minimum wage on employment remains negative and statistically significant for the youth group as a whole, but is essentially zero for teenagers. However, these results should not be interpreted too literally, given that tests of whether including the additional characteristics of minimum wage systems adequately captures the cross-country variation in employment rates reject the exclusion of the country effects for both youths and teenagers.

\footnotetext{
${ }^{17}$ This classification is also subject to some discretion. Countries for which we classified youth subminimum wages as important in our sample include Australia, Belgium, Denmark, Luxembourg, the Netherlands, New Zealand, Portugal, Spain, Sweden, and the U.K. Countries that we classified as having no or limited youth subminimum provisions include Canada, France, Germany, Greece, Italy, Japan, and the U.S.

${ }_{18}$ Such an effect could be particularly important if the youth subminimum is low enough to be essentially non-binding.

${ }^{19}$ Including country-specific time trends without fixed country effects would appear to impose the restriction that observations across countries can only diverge over time because of the time trends. However, the dummy variables
} 
In the remaining columns of the table, therefore, we include fixed country effects, and proceed to the central question of estimating how the effects of the minimum wage on employment differ with the country-specific characteristics of minimum wage systems. Columns (2) and (5) present the standard fixed effects specification that includes year effects and country-specific time trends, while columns (3) and (6) report coefficients from the dynamic employment model estimated using GMM. Turning first to how minimum wages are set, the results for both youths and teenagers indicate that countries where the minimum wage is determined through the collective bargaining process tend to exhibit a smaller negative impact of minimum wages, although the coefficient on the minimum wage interacted with the collective bargaining dummy is statistically significant only at the $10 \%$ level for youths and is well short of standard significance levels for teenagers. In contrast, the coefficients on the indicator of subnational variation in the minimum wage indicate that the presence of industry or geographic wage floors tends to increase the disemployment effects of the minimum wage, which might suggest that such variation is primarily used to raise the overall level of the minimum wage to levels where disemployment effects set in, rather than to target minimum wages to relative productivity levels in particular industries or to living costs in particular regions. However, the standard errors surrounding these estimates are also relatively large. Finally, the presence of a youth subminimum consistently reduces the negative consequences of the minimum wage, with especially large effects evident for teenagers. These results are consistent with our suspicion that by using the adult minimum wage in constructing the minimum wage ratio, we overstated the relevant (or "effective") minimum wage for the age groups under study in some countries. In addition, the positive coefficient on the youth subminimum dummy may be an indication that such provisions lead employers to substitute lower-cost youths for low-skilled adult workers who are subject to the full minimum wage.

These results must be interpreted cautiously. They do not necessarily mean, for example, that in a country with a national minimum wage there are no disemployment effects of minimum wages. As Table 1 indicates, countries differ simultaneously in terms of how minimum wages are set, whether the wage floors are national or subnational in scope, and whether the law allows for youth subminimum wage rates. Furthermore, along these and other dimensions each country is to some extent unique, and a disaggregated approach that tries to fully account for this uniqueness would take us back to individual country studies, entailing some potential gains but also the loss of the cross-national variation. Nonetheless, we believe these estimates are informative regarding some of the institutional features of minimum wage systems that are more or less likely to cause minimum wage increases to be associated with declines in youth employment.

for features of minimum wage systems allow some intercept differences among countries, and the idea underlying this specification (which is tested) is that these dummy variables adequately capture the fixed differences across countries. 


\section{The Sensitivity of Minimum Wage Effects to Other Labor Market Policies and Institutions}

Another dimension along which differences across countries might influence the effects of the minimum wage on youth labor markets is variation in other labor market policies and institutions. For example, a country raising its minimum wage in the presence of other labor market rigidities, such as restrictions on adjusting hours or using flexible contracts, might experience larger disemployment effects than a country where employers have alternatives to adjusting employment levels. In contrast, if a country couples an increase in the minimum wage with policies designed to bring unemployed individuals back into the work force, the disemployment effects of minimum wages might be hidden by an increase in the use of such active labor market policies. ${ }^{20}$

In Table 5, we report indices developed by the OECD as indicators of the importance of other such labor market policies and institutions in the countries in our sample. The first is a labor standards index, which is constructed from OECD characterizations of the rigidity of labor standards in three areas: legislated working time rules, the ability of employers to use flexible employment contracts, and workers' representation rights. In particular, each category is assigned a value from 0 to 2 (with 0 meaning that government regulations are light and 2 meaning that regulations are strict), and the values are summed to form the index. Thus, high values of the index (such as those in Greece and Sweden) indicate the presence of substantial rigidities associated with labor standards, whereas low values (e.g., the U.K. and the U.S.) are suggestive of more flexibility.

The second measure we use provides information on employment protection regulations across countries. This index, which also was constructed by the OECD, is based on rankings of countries according to the "strength of the legal framework governing hiring and firing" (Nickell, 1997, p. 60), and covers: regular procedural inconveniences (in terms of the types of procedures that need to be followed to dismiss an employee and the delay associated with following such procedures), notice and severance pay requirements for no-fault dismissals, and the difficulty of dismissal (e.g., what constitutes an unfair dismissal, how long after a dismissal an appeal can be made, and the penalties associated with an unfair

dismissal ruling). ${ }^{21}$ Paralleling the labor standards index, high values are associated with countries having a high degree of employee protection, while low values indicate relative ease in dismissing employees. In Coe and Snower (1997), more restrictive job security measures reduce employment levels and exacerbate the negative employment effects of minimum wages. However, the theoretical literature is not in

\footnotetext{
${ }^{20}$ In that case, any disemployment effects of the minimum wage might appear as higher government spending rather than lower employment rates.

${ }^{21}$ See Chapter 6 of OECD (1994) for details. Nickell (1997) has also used these two measures of labor market rigidities.
} 
agreement on this point, and empirical estimates of the effect of employment protection on employment rates range from zero to a sizable negative effect. ${ }^{22}$

A third measure we consider is the extent to which the public sector in each country uses active labor market policies to bring unemployed individuals into the work force. Such policies could include public employment services (e.g., job search assistance), labor market training programs, or employment creation programs, either in the form of subsidies to private employers or direct job creation. This variable is defined as the level of public expenditures on such programs in 1995 as a percent of GDP, so that a higher value indicates a greater commitment on the part of a particular country to such policies and institutions.

The indicators of these labor market policies and institutions are cross-sectional in nature, and as can be seen in the bottom row of Table 5, all are positively correlated with the level of relative minimum wages across countries. However, we also considered two measures for which time-varying data were available. The first of these measures is union coverage, which is taken from Nickell and Nunziata (2001) and defined as the percentage of wage and salary workers who are members of a union. On the one hand, the employment security provided by unions might be expected to shift the employment losses resulting from a higher minimum wage onto non-covered workers, who are more likely to be young. On the other hand, the presence of unions might also raise wages above the minimum for competing low-skilled workers, thus mitigating the relative wage changes and disemployment effects that might arise from a higher minimum wage. The second variable is a measure of the generosity of unemployment insurance programs, defined as the average gross benefit replacement rate (as a percent of earnings) and constructed by the OECD. In the Coe and Snower model of policy complementarities, more generous unemployment insurance reduces the number of active job searchers in the economy, which exacerbates the negative employment effects of a higher minimum wage by counteracting any positive labor supply response. As shown in the bottom panel, the means of these indicators are also positively correlated with the average minimum wage ratio, although somewhat less so than the three cross-sectional variables.

In Table 6, we present results from specifications that include these other labor market policy/institution variables. ${ }^{23}$ As before, the specifications are similar to those in Table 3 and include the adult unemployment rate, the relative cohort size variable, and the other sets of controls. As in Table 4, the first column for each age group excludes the fixed country effects and instead adds the policy variables to the model as a means of controlling for other factors that are both correlated with minimum wages and could potentially affect youth employment rates, without necessarily stripping out the between-country covariation between minimum wages and youth employment. In these specifications, the overall

\footnotetext{
${ }^{22}$ See, for example, Bentolila and Bertola (1990), Bertola (1990), Lazear (1990), and Scarpetta (1996).
} 
coefficients on the minimum wage ratio are negative and significant. The point estimates, at -0.30 for all youths and -0.39 for teenagers, are somewhat larger (in absolute value) than those reported in column (1) of Table 3, indicating that the magnitudes of the estimated disemployment effects in those earlier specifications were held down by the omission of information on labor market policies and institutions.

Regarding the estimated effects of the labor market policy variables on employment, for the youth group as a whole (column (1)), countries with more restrictive labor standards (in terms of working time, flexible employment contracts, and worker representation rights) and with more generous unemployment insurance benefits tend to have lower employment rates than other countries. Unemployment insurance also has a depressing effect on teen employment rates (column (4)), but more restrictive labor standards appear to be of little relevance for the employment probabilities of this younger age group. In contrast, active labor market policies and stronger employment protection legislation are associated with higher employment rates in these specifications. The positive coefficient on active labor market policies is perhaps not surprising given the stated purpose of such policies. However, the estimated positive effect from employment protection legislation contrasts with the usual finding in the literature. Finally, union density is estimated to have essentially no effect on the employment rate for the youth group as a whole, but a positive effect on the employment of teenagers.

As in Table 4, however, we can reject the hypothesis that the inclusion of these additional labor market policy variables adequately captures the fixed cross-country variation in employment rates. Thus, we focus on the estimates in the remaining columns ((2), (3), (5), and (6)), in which we replace the crosssectional indicators of other labor market policies and institutions with the fixed country effects. ${ }^{24}$ As in previous tables, the overall effect of the minimum wage becomes smaller when fixed effects are included, dropping to the low end of the estimates reported in Table 3. However, the more important findings concern the influence of variations in these labor market policies on the size of the disemployment effects from minimum wages; these are shown by the coefficients in the bottom half of the table. In these specifications there is strong evidence of interactions between the effects of minimum wage laws and the presence of other labor market policies. ${ }^{25}$

In most cases, the signs of the coefficients are the same as the estimated effects of the policy variables on employment from the specifications that exclude the fixed effects, a results that seems

\footnotetext{
${ }^{23}$ These regressions exclude Luxembourg because of a lack of data on other labor market policies and institutions for that country. However, excluding Luxembourg from the specifications in Table 3 had no material effect on those results.

${ }^{24}$ The UI replacement rate and union density vary over time and thus are included in these specifications.

${ }^{25}$ For the results reported in this table, the policy variables were differenced from their mean values and divided by their standard deviations prior to estimation (and prior to forming the interactions). Thus, the coefficients on these policy variables can be interpreted as the effect of a one standard deviation change in the associated labor market
} 
consistent with Coe and Snower's hypothesis that labor market policy variables are likely to have complementary effects. In particular, more restrictive labor standards tend to exacerbate the disemployment effects of minimum wages, consistent with the notion that such standards force more of the adjustment to a higher minimum to occur through the employment channel. In contrast, stricter employment protection regulations are estimated to offset the negative employment consequences of a wage floor, perhaps because it is more costly to dismiss workers in countries with such regulations. The fixed-effects specifications also provide evidence that the presence of more active labor market policies or institutions tends to reduce the size of the minimum wage effect, perhaps because they absorb some of the workers displaced from private-sector jobs by a higher wage floor. Alternatively, active labor market policies (e.g., training) may provide the means for low-skilled workers to raise their productivity to a level permitting employment at the minimum wage. UI replacement rates do not seem do have any measurable impact on the disemployment effects of minimum wages, despite evidence that they reduce employment levels more generally. In contrast, in some specifications higher union coverage leads to a more negative estimate of the minimum wage coefficient, a finding consistent with Coe and Snower's hypothesis that the effect of the minimum wage on employment may be magnified by an increase in the bargaining power of incumbent workers.

\section{Differences in Minimum Wage Effects Across Countries}

Although we have focused thus far on the signs of the coefficients on the interactions between the labor market policy and institution variables and the minimum wage ratio, the magnitudes of the estimated coefficients are sufficiently large to suggest that minimum wage effects may vary considerably across countries. This point is illustrated in Table 7, in which we report the variation in minimum wage effects across sets of countries differentiated by the importance of the labor market policies and institutions included in the regressions shown in Table 6. In particular, we have grouped the countries in our sample into four distinct categories: countries with restrictive labor standards and high levels of both employment protection laws and active labor market policies (e.g., Germany and Italy); countries with restrictive labor standards and low levels of employment protection laws and active policies (e.g., Netherlands and Greece); countries with less restrictive labor standards but high levels of employment projection laws and active policies (e.g., Belgium and Portugal); and countries with less restrictive labor standards and low levels of employment protection laws and active policies (e.g., the U.S. and U.K.). ${ }^{26}$

policies index, while the minimum wage coefficient can be interpreted as the effect of the minimum wage for a hypothetical country with each policy variable equal to its sample average.

${ }^{26}$ We consider employment protection and active labor market policies together because their estimated interactions with the minimum wage in the employment regressions in Table 6 were of the same sign. The classification of countries by the two rows in Table 7 is based on whether the rank of the country in terms of the labor standards index in Table 5 is less than or greater than 8 (the median rank), and the average ranks of the employment protection and 
In each panel of the table we first report the implied effect for each country based on the coefficients in column (3) or (6) of Table 6 and that country's values for each of the policy variables. Below the country-specific estimates, we present implied average effects using the coefficients in Table 6 and the average value of each policy variable for the countries in that panel. We also present an estimate of the average minimum wage effect for each set of countries based on the dynamic specification shown in column (6) of Table 3, but allowing the minimum wage effect to differ across the sets of countries in each panel. $^{27}$

Focusing initially on the upper-left panel, countries with restrictive labor standards and generous levels of employment protection laws and active labor market policies tend to exhibit a small positive minimum wage effect for youth employment and a small negative effect for teenagers. Looking back to Table 6, these small net effects of minimum wages stem from the offsetting impacts of labor standards, employment protection, and active labor market policies on the overall minimum wage coefficient. The directly estimated effects are positive (and statistically significant for youths). As indicated in the bottomleft panel, the implied coefficients become even more positive for the set of countries with less restrictive labor standards and high average values for the employment protection and active labor market policies indices, consistent with the result in Table 6 that restrictive labor standards are associated with more adverse effects of minimum wages. However, these higher implied coefficient values are not statistically significant and are not matched by more positive direct estimates of minimum wage effects for this set of countries.

In contrast, for the panels on the right-hand side of the table, which show sets of countries with low levels of employment protection and active labor market policies, the minimum wage effects are predominantly negative, reflecting the finding in Table 6 that countries with weaker employment protection and active labor market policies face more adverse consequences from minimum wages. For the set of countries that also have restrictive labor standards (the upper-right panel), the average implied effect is in the -0.2 to -0.4 range, although the estimates of the minimum wage effect are only statistically significant for youths.

For the set of countries that also have less restrictive labor standards (the lower-right panel), the minimum wage effects are consistently negative and nearly always statistically significant. Note that going from the upper-right to the lower-right panel should, all else the same, moderate the disemployment effects of minimum wages, as the results in Table 6 indicate that lower labor standards are associated with less

active labor market policies indices are used in the same way to classify countries by the two columns in Table 7 . (The ranks for each country are reported in parentheses in Table 7.)

${ }^{27}$ For all of the estimates shown in Table 7, the specification includes fixed country effects, year effects, time trends, and the control variables shown in column (6) of Table 3. The models are estimated using the Arellano-Bond GMM technique. 
adverse minimum wage effects. But all else is not the same, as the countries in the lower-right panel also have less stringent employment protection and weaker active labor market policies than those in the upperright panel; this is indicated by the rankings of the countries displayed to the right of each country's name. The most direct implication of the results reported in Table 7 is that the neoclassical disemployment effects of minimum wages are most apparent for the countries with the least regulated labor markets.

We hasten to emphasize that we do not regard the specifications used in Tables 6 and 7 as necessarily providing reliable estimates of minimum wage effects for each country, but rather as providing some indication of how the magnitudes of minimum wage effects vary with other labor market policies and institutions. In particular, the measures of the regulatory environment in each country are rough and incomplete, and thus they probably should be interpreted as ordinal rankings of the various labor market policies rather than as explicit estimates of the exact degree of the strength of labor market regulations. Nonetheless, the evidence indicates that the interactions of minimum wages with other labor market policies and institutions are sufficiently strong so that results for one country should not blindly be applied to other countries, especially when considering countries with substantially different policies and institutions regulating labor markets.

\section{Conclusions}

We have attempted to exploit the substantial differences across countries in minimum wage laws and other labor market policies and institutions to obtain new estimates of the employment effects of the minimum wage. Although reference is often made to the importance of such differences in explaining labor market outcomes across countries, there have been relatively few studies that attempt to test such propositions directly. Using a panel data approach similar to recent studies that exploit regional or industry differences within a country, we investigate the role that minimum wages play in determining youth employment rates in 17 industrialized countries, and how labor market policies and institutions influence minimum wage effects.

In general, our results provide evidence that minimum wages tend to reduce employment rates among the youth population. A clear negative correlation between the level of the minimum wage and youth employment-to-population ratios appears both in the raw data, and in time-series cross-section regressions relating employment rates to minimum wages, with controls for overall economic conditions and crosscountry variation in labor market policies and institutions. The disemployment effects also appear in models that control for country-specific factors (including country-specific time trends), indicating that the results are not solely driven by cross-country differences in minimum wage levels and youth employment rates.

The evidence also suggests that the impact of minimum wages differs substantially across the countries in our sample. In attempting to identify the sources of such differences, we have focused on two specific areas that might be expected to lead to some variation in the employment effects of minimum 
wages. The first is the role played by other cross-country differences in minimum wage systems. We find, in this regard, that the negative relationship across countries between youth employment and minimum wages is smaller when the wage floor is set by the collective bargaining process and that the presence of a youth subminimum wage tends to reduce the negative impact of the overall minimum wage on teen employment. In contrast, countries with substantial regional or industry variation in minimum wage rates tend to exhibit larger negative minimum wage effects on youth employment rates.

The second source of variability we consider — and on which we focus more attention - is the presence of other labor market policies or institutions that theory suggests could either exacerbate or mitigate the effects of minimum wage laws. Our results suggest that such policies potentially can have important influences on the size of the disemployment effects stemming from wage floors. In particular, our estimates indicate that the presence of rigid labor standards tends to exacerbate the effects of the minimum wage on employment, while stronger employment protection policies or greater use of active labor market policies to reduce unemployment tend to offset the minimum wage effect. On net, however, the results indicate quite strongly that in the least regulated labor markets in the sample - namely the U.S., U.K., Canada, and Japan — minimum wages reduce employment. These findings thus highlight the importance of accounting for institutional and other policy-related differences when using data for different countries to study the effects of economic policies such as the minimum wage, and, from a policy perspective, when predicting the effects of changes in the minimum wage for particular countries. 


\section{Appendix:}

\section{Definitions of the Minimum Wage Variable and Other Information on Minimum Wage Systems}

\section{$\underline{\text { Australia }}$}

Definition of minimum wage variable: The federal minimum weekly wage divided by the median gross weekly earnings of full-time workers. Prior to 1997, the federal minimum is extrapolated based on Metal Industry Award C14 wages and National Wage Case decisions. Source: OECD Minimum Wage Database.

Method of setting: An independent Commission (Australian Industrial Relations Commission or AIRC) is responsible for setting the federal minimum wage via an annual Safety Net Review. Although some statelevel legislation also exists, the federal minimum wage is applicable to the majority of Australian workers.

Other provisions: Minimum wages may differ by industry and occupation if the AIRC approves applications to vary minimum award rates from the federal level. There is also a youth subminimum, with rates ranging from $40 \%$ to $85 \%$ of the adult minimum depending on age.

\section{$\underline{\text { Belgium }}$}

Definition of minimum wage variable: The minimum monthly wage for workers aged 21 and over divided by the median gross monthly earnings of full-time workers. Source: OECD Minimum Wage Database.

Method of setting: The private-sector minimum wage (Revenue Minimum Mensuel Moyen Garanti) is set via a biennial national collective bargaining agreement between social partners (employers and unions) within the Conseil National du Travail. This minimum wage is then made mandatory for the entire private sector by royal decree. Between collective bargaining agreements, the minimum wage is indexed to the consumer price index, with a formula that adjusts up the minimum two months following a cumulative 2 percent increase in the CPI.

Other provisions: The laws provide for a subminimum wage for employees less than 21 years of age. This subminimum wage is $70 \%$ of the adult minimum for employees aged 16 or under, with the proportion rising by 6 percentage points for each extra year of age.

\section{Canada}

Definition of minimum wage variable: Weighted average of provincial hourly minimum wage levels (weighted by the size of the labor force in each province) divided by median gross hourly earnings of fulltime workers. Source: OECD Minimum Wage Database.

Method of setting: Minimum wages are set separately in each province and territory either by minimum wage boards or by the Lieutenant-Governor in Council.

Other provisions: In most provinces, a single minimum wage applies to workers aged 16 and over. An exception is Ontario, which allows a slightly lower minimum wage rate to be paid to students under 18 years of age. 


\section{Denmark}

Definition of minimum wage variable: The average hourly minimum wage divided by an average hourly wage. Source: Dolado, et al. (1996).

Method of setting: There is no legally-mandated national minimum wage. Instead, minimum hourly wage rates are set via centralized industry-level collective bargaining agreements, which may be supplemented by agreements at the plant level.

Other provisions: Minimum wages may vary considerably at the industry level. In addition, workers under 18 years of age are generally subject to a lower minimum wage.

\section{Finland}

Definition of minimum wage variable: Average monthly minimum wage divided by an average monthly wage. Source: Dolado, et al. (1996).

Method of setting: There is no legislated national minimum wage. Instead, minimum wage rates are set via centralized industry-level collective bargaining agreements. The law requires all employersincluding nonunion employers - to pay the minimum rates contained in these collective bargaining agreements.

Other provisions: Minimum wages may vary considerably at the industry level.

\section{France}

Definition of minimum wage variable: Gross annual equivalent of the annual minimum wage divided by median gross annual earnings of full-time workers in the private and semi-private sector. Source: OECD Minimum Wage Database.

Method of setting: The minimum wage (Salaire Minimum Interprofessional de Croissance, or SMIC) is set by the government. Administrative procedures are used to adjust the SMIC each July to reflect both consumer price increases and real wage increases in the hourly wages of manual workers. In addition, the government has sometimes enacted additional increases in the minimum wage.

Other provisions: Limited youth subminimum wage rates are applicable to workers under the age of 18 . Specifically, workers aged 16 can be paid $80 \%$ of the adult minimum, while workers aged 17 can be paid $90 \%$ of the adult minimum for six months.

\section{Germany}

Definition of minimum wage variable: Average monthly minimum wage divided by an average monthly wage. Source: Dolado, et al. (1996).

Method of setting: There is no legislated national minimum wage. Instead, minimum wage rates are set via industry-specific collective bargaining agreements. These agreements can be extended to all employers in the industry if the workforce of the employers directly affected by the agreement comprises at least $50 \%$ of the total workforce in that industry. In addition, the government may call for a Hauptausschu $\beta$ commission - consisting of the government, employers, and employees - to set minimum wage levels in industries where unions represent only a minority of employees. 
Other provisions: Minimum wages may vary considerably at the industry level. Some industry agreements include youth subminimum wage rates.

\section{Greece}

Definition of minimum wage variable: Minimum daily wage for an unqualified single worker with no work experience (converted to an hourly rate by assuming an 8 hour work day) divided by the mean hourly wage in manufacturing. Source: OECD Minimum Wage Database.

Method of setting: The national minimum wage level is negotiated annually by representatives of the General Confederation of Greek Workers and the main employer organizations (facilitated by arbitration if necessary). The negotiated level is routinely ratified by the Ministry of Labor and is applicable to all workers.

Other provisions: The minimum wage varies slightly by tenure and by marital status.

\section{Ireland}

Definition of minimum wage variable: Minimum gross hourly wage divided by median weekly earnings of full-time employees (converted to an hourly rate). Source: OECD Minimum Wage Database.

Method of setting: The government enacted a national minimum wage in April 2000. This minimum wage is reviewed annually by the independent Low Pay Commission, which then recommends an increase for consideration by the government. Prior to that legislation, statutory minimum wages were set by Joint Labour Committees in a limited number of low-wage industries. These Labour Committees consisted of equal numbers of representatives of employers and workers appointed by the Labour Court and a chairman appointed by the Minister for Enterprise, Trade, and Employment.

Other provisions: Under current law, workers under the age of 18 can be paid $70 \%$ of the adult minimum wage.

\section{Italy}

Definition of minimum wage variable: Average minimum monthly wage divided by an average wage. Source: Dolado, et al. (1996).

Method of setting: There is no legislated national minimum wage. Instead, minimum wage rates typically are set via industry-specific national collective bargaining agreements, which then are applicable to all workers in the industry.

Other provisions: Minimum wages may vary considerably at the industry level. Some industry agreements include youth subminimum wage rates.

\section{$\underline{\text { Japan }}$}

Definition of minimum wage variable: Weighted average of prefectural hourly minimum wage levels (weighted by the size of the labor force in each prefect) divided by median gross monthly earnings (converted to hourly basis using average monthly hours worked). Source: OECD Minimum Wage Database. 
Method of setting: Minimum wages are set by prefecture, typically by the Labor Minister or by the Chief of the Prefectural Labor Standards Office based on advice from the Central Council on Minimum Wages.

Other provisions: None.

\section{Luxembourg}

Definition of minimum wage variable: Minimum monthly wage divided by median gross annual earnings of full-time workers (divided by 12). Source: OECD Minimum Wage Database.

Method of setting: The minimum wage (Salaire Social Minimum) is set by law and is automatically updated by the change in the cost of living index. In addition, the government is required to reevaluate the real value of the minimum every two years, and if deemed necessary, to propose a new level. In practice, these adjustments have been based on the change in the average real hourly wage over the preceding two years.

Other provisions: The laws provide for a subminimum wage for employees less than 18 years of age. This subminimum wage is $80 \%$ of the adult minimum for employees aged $17,70 \%$ for those aged 16 , and $40 \%$ for those aged 15 .

\section{$\underline{\text { Netherlands }}$}

Definition of minimum wage variable: Minimum weekly earnings for persons aged 23 to 64 divided by median gross annual earnings of full-time employees (divided by 52). Source: OECD Minimum Wage Database.

Method of setting: The minimum wage (Minimumloon) is set by law and is normally updated in January and July of each year based on the average increase in wages negotiated in the private sector. The government may choose to suspend or alter the increase if the unemployment rate is above a certain level.

Other provisions: The laws provide for a subminimum wage for employees less than 23 years of age. This subminimum wage ranges from $85 \%$ of the adult minimum for employees aged 22 to $30 \%$ for those less than 17.

\section{$\underline{\text { New Zealand }}$}

Definition of minimum wage variable: Minimum weekly wage for workers aged 20 and over divided by median usual weekly earnings of full-time employees. Source: OECD Minimum Wage Database.

Method of setting: The minimum wage is set by the government based on an annual review by the Ministry of Enterprise and Commerce.

Other provisions: Prior to 2000, workers under the age of 20 could be paid $60 \%$ of the adult minimum wage. In 2000, new legislation restricted applicability of the subminimum wage to those workers under age 18 .

\section{Norway}

Definition of minimum wage variable: Average minimum hourly wage divided by an average wage. Source: Dolado, et al. (1996). 
Method of setting: There is no legislated national minimum wage. Instead, minimum wage rates typically are set via industry-specific national collective bargaining agreements, which can then be extended to cover all workers in the industry.

Other provisions: Minimum wages may vary considerably at the industry level.

\section{Portugal}

Definition of minimum wage variable: Minimum monthly wage for nonagricultural workers aged 20 and over divided by median gross annual earnings of full-time workers (divided by 12). Source: OECD Minimum Wage Database.

Method of setting: The minimum wage (Salário Minimo Nacional) is set annually by the government after consultation with the Permanent Commission for Social Cooperation.

Other provisions: Under current law, workers under the age of 18 can be paid $75 \%$ of the adult minimum wage. Prior to 1987, workers aged 18 and 19 were also eligible for subminimum wage rates.

\section{$\underline{\text { Spain }}$}

Definition of minimum wage variable: Minimum monthly wage for workers aged 18 and over divided by median gross annual earnings of full-time workers (divided by 12). Source: OECD Minimum Wage Database.

Method of setting: The minimum wage (Salario Minimo Interprofesional) is set annually by government decree, with the amount of any increase determined by the Council of Ministers.

Other provisions: Under current law, all workers aged 16 and over are subject to the adult minimum wage. Prior to 1999, workers under the age of 18 could be paid less than the adult minimum wage.

\section{Sweden}

Definition of minimum wage variable: The average hourly minimum wage divided by an average hourly wage. Source: Dolado, et al. (1996).

Method of setting: There is no legislated national minimum wage. Instead, minimum wage rates typically are set via industry-specific national collective bargaining agreements, which then are applicable to all workers in the industry.

Other provisions: Private sector agreements typically specify separate minimum wage rates for adult workers (ages 24 and above) and youths.

\section{$\underline{\text { United Kingdom }}$}

Definition of minimum wage variable: Beginning in 1999, national hourly minimum wage divided by median hourly earnings of full-time adult employees. Source: OECD Minimum Wage Database. Prior to 1993, the average minimum wage in Wages Council sectors divided by an average wage. Source: Dolado, et al. (1996). There was no minimum wage from August 1993 through March 1999.

Method of setting: Under current law, minimum wage levels are reviewed regularly based on recommendations from the independent Low Pay Commission. Prior to 1993, minimum wages were set in 
certain industries by Wage Councils, which were originally set up to protect low-wage workers who were not covered by collective bargaining agreements.

Other provisions: Under current law, workers aged 18 to 21 may be paid about $85 \%$ percent of the current adult minimum wage; workers under age 18 are exempt from the minimum wage. Prior to 1993, minimum wage rates differed substantially by industry, age, and region. Beginning in 1986, all workers under age 21 were exempt from minimum wage laws.

\section{$\underline{\text { United States }}$}

Definition of minimum wage variable: Federal minimum hourly wage divided by median usual weekly earnings of full-time employees (converted to an hourly rate by assuming a 40 hour full-time workweek). Source: OECD Minimum Wage Database.

Method of setting: The national minimum wage level is set by the government and can only be updated by legislative action.

Other provisions: States have the ability to set a minimum wage above the federal level. Subminimum wage rates may be paid to selected full-time students and newly-hired youths (for 90 days). 


\section{References}

Abowd, John, Francis Kramarz, Thomas Lemieux, and David Margolis. 1997. "Minimum Wages and Youth Employment in France and the United States." National Bureau of Economic Research, Working Paper No. 6111.

Arellano, Manuel, and Stephen Bond. 1991. "Some Tests of Specification for Panel Data: MonteCarlo Evidence and an Application to Employment Equations." The Review of Economic Studies, Vol. 58, No. 2, pp. 277-97.

Baker, Michael, Dwayne Benjamin, and Shuchita Stanger. 1999. "The Highs and Lows of the Minimum Wage Effect: A Time Series-Cross Section Study of the Canadian Law." Journal of Labor Economics, Vol. 17, No. 2, pp. 318-50.

Bazen, Stephen, and Nicolas Skourias. 1997. "Is There a Negative Effect of Minimum Wages in France?” European Economic Review, Vol. 41, No. 3-5, pp. 723-32.

Bentolila, Samuel, and Giuseppe Bertola. 1990. "Firing Costs and Labour Demand: How Bad is Eurosclerosis?” The Review of Economic Studies, Vol. 57, No. 3, pp. 381-402.

Bertola, Giuseppe. 1990. "Job Security, Employment and Wages.” European Economic Review, Vol. 34, No. 4, pp. 851-79.

Blanchard, Olivier, and Justin Wolfers. 2000. "The Role of Shocks and Institutions in the Rise of

European Unemployment: the Aggregate Evidence." The Economic Journal, Vol. 110, No. 3, pp. C1-C33.

Blau, Francine D., and Lawrence M. Kahn. 1996. "International Differences in Male Wage Inequality: Institutions versus Market Forces.” Journal of Political Economy, Vol. 104, No. 4, pp. 791 837.

Card, David, and Alan Krueger. 1995. Myth and Measurement: The New Economics of the Minimum Wage. Princeton, NJ: Princeton University Press.

Chapple, S. 1997. "Do Minimum Wages Have an Adverse Impact on Employment? Evidence from New Zealand.” Labour Market Bulletin, Vol. 2, pp. 25-50.

Coe, David T., and Dennis J. Snower. 1997. "Policy Complementarities: The Case for Fundamental Labor Market Reform.” IMF Staff Papers, Vol. 44, No. 1, pp. 1-35.

Di Tella, Rafael, and Robert MacCulloch. Forthcoming. "The Consequences of Labour Market Flexibility: Panel Evidence Based on Survey Data." European Economic Review.

Dolado, Juan, Francis Kramarz, Stephen Machin, Alan Manning, David Margolis, and Coen Teulings. 1996. "The Economic Impact of Minimum Wages in Europe." Economic Policy, Vol. 23 (October), pp. 319-70.

Dolado, Juan, Florentino Felgueroso, and Jan Jimeno. 1997. "The Effects of Minimum Bargained Wages on Earnings: Evidence from Spain. European Economic Review, Vol. 41, No. 3-5, pp. 713-21.

European Commission. 1998. Minimum Wages in 1997-A Comparative Study. Luxembourg: Office for Official Publications of the European Communities.

Hamermesh, Daniel. 2002. "International Labor Economics.” Journal of Labor Economics, Vol. 20, No. 4, pp. 709-32.

Kahn, Lawrence M. 2000. "Wage Inequality, Collective Bargaining, and Relative Employment from 1985 to 1994: Evidence from Fifteen OECD Countries." The Review of Economics and Statistics, Vol. 82, No. 4, pp. 564-79. 
Korenman, Sanders, and David Neumark. 2000. "Cohort Crowding and Youth Labor Markets: A Cross-National Analysis." In David Blanchflower and Richard Freeman, eds., Youth Employment and Unemployment in Advanced Countries. Chicago: University of Chicago Press, pp. 57-105.

Lazear, Edward P. 1990. "Job Security Provisions and Employment." The Quarterly Journal of Economics, Vol. 105, No. 3, pp. 699-726.

Machin, Stephen, and Alan Manning. 1994. "The Effects of Minimum Wages on Wage Dispersion and Employment: Evidence from the U.K. Wage Councils." Industrial and Labor Relations Review, Vol. 47, No. 2, pp. 319-29.

Machin, Stephen, and Alan Manning. 1996. "Employment and the Introduction of a Minimum Wage in Britain.” The Economic Journal, Vol. 106, No. 436, pp. 667-76.

Machin, Stephen, and Alan Manning. 1997. "Minimum Wages and Economic Outcomes in Europe.” European Economic Review, Vol. 41, No. 3-5, pp. 733-42.

Maloney, T. 1995. "Does the Adult Minimum Wage Affect Employment and Unemployment in New Zealand?” New Zealand Economic Papers, Vol. 1, pp. 1-19.

Mare, D. 1995. “Comments on Maloney.” Unpublished paper, New Zealand Department of Labour.

Minford, P., and P. Ashton. 1996. "Minimum Wages: A Macroeconomic Assessment.” Unpublished paper, University of Liverpool.

Neumark, David, and William Wascher. 1992. "Employment Effects of Minimum and Subminimum Wages: Panel Data on State Minimum Wage Laws." Industrial and Labor Relations Review, Vol. 46, No. 1, pp. 55-81.

Neumark, David, and William Wascher. 1996. "Reconciling the Evidence on Employment Effects of Minimum Wages: A Review of Our Research Findings.” In Marvin Kosters, ed., The Effects of Minimum Wages on Employment. Washington, DC: American Enterprise Institute, pp. 55-86.

Nickell, Stephen. 1981. "Biases in Dynamic Models with Fixed Effects." Econometrica, Vol. 49, No. 6, pp. 1417-26.

Nickell, Stephen. 1997. "Unemployment and Labor Market Rigidities: Europe versus North America." Journal of Economic Perspectives, Vol. 11, No. 3, pp. 55-74.

Nickell, Stephen, and Luca Nunziata. 2001. “Labour Market Institutions Database.” Unpublished paper, Centre for Economic Performance, London School of Economics.

Organisation for Economic Co-operation and Development. 1994. The OECD Jobs Study: Evidence and Explanations, Part II: The Adjustment Potential of the Labour Market. Paris: OECD.

Organisation for Economic Co-operation and Development. 1996. Employment Outlook. Paris: OECD.

Organisation for Economic Co-operation and Development. 1998. Employment Outlook. Paris: OECD.

Organisation for Economic Co-operation and Development. 1999. Employment Outlook. Paris: OECD.

Organisation for Economic Co-operation and Development. 2001. Labour Force Statistics 19802000. Paris: OECD.

Pereira, Sonia C. Forthcoming. "The Impact of Minimum Wages on Youth Employment in Portugal.” European Economic Review. 
Portugal, Pedro, and Ana Rute Cardoso. 2002. "Disentangling the Minimum Wage Puzzle: An Analysis of Worker Accessions and Separations." Discussion Paper No. 544, Institute for the Study of Labor (IZA).

Scarpetta, Stefano. 1996. "Assessing the Role of Labour Market Policies and Institutional Settings on Unemployment: A Cross-Country Study.” OECD Economic Studies, Vol. 26, pp. 43-98.

Siebert, Horst. 1997. "Labor Market Rigidities: At the Root of Unemployment in Europe.” Journal of Economic Perspectives, Vol. 11, No. 1, pp. 37-54.

United States Department of State. 2001. Country Reports on Human Rights Practices. Washington, DC: Government Printing Office.

United Kingdom Low Pay Commission. 2001. The National Minimum Wage: Third Report. London: Low Pay Commission.

Van Soest, A. 1994. "Youth Minimum Wage Rates: The Dutch Experience.” International Journal of Manpower, Vol. 15, No. 2, pp. 100-17. 
Table 1

\section{Minimum Wage Levels and Other Characteristics of Minimum Wages in Selected Countries}

\begin{tabular}{|c|c|c|c|c|c|}
\hline \multirow[b]{2}{*}{ Country } & \multicolumn{2}{|c|}{$\begin{array}{l}\text { Ratio of Minimum Wage } \\
\text { to Average Wage }\end{array}$} & \multicolumn{3}{|c|}{$\begin{array}{c}\text { Other Characteristics of } \\
\text { Minimum Wage Systems (1993) }\end{array}$} \\
\hline & 1976 & 2000 & $\begin{array}{l}\text { Method for } \\
\text { Setting }\end{array}$ & Level & $\begin{array}{c}\text { Youth } \\
\text { Subminimum }\end{array}$ \\
\hline Italy (1991) & 0.78 & 0.71 & Negotiated & Industry & Some \\
\hline Norway (1994) & -- & 0.64 & Negotiated & Industry & No \\
\hline France & 0.58 & 0.62 & Statute & National & Limited, $<18$ \\
\hline Australia & $0.65^{1}$ & 0.58 & Statute & National & $<21$ \\
\hline Germany (1994) & 0.60 & 0.58 & Negotiated & Industry & Some \\
\hline Ireland & -- & 0.56 & $\begin{array}{c}\text { Labor } \\
\text { Committees }\end{array}$ & Industry & $<18$ \\
\hline Denmark (1994) & 0.59 & 0.54 & Negotiated & Industry & $<18$ \\
\hline Finland (1993) & -- & 0.52 & Negotiated & $\begin{array}{l}\text { Industry, } \\
\text { Region }\end{array}$ & No \\
\hline Greece & 0.69 & 0.51 & Negotiated & National & No \\
\hline Sweden (1992) & 0.52 & 0.51 & Negotiated & Industry & $<24$ \\
\hline Belgium & 0.58 & 0.49 & Negotiated & National & $<21$ \\
\hline Luxembourg & 0.41 & 0.49 & Statute & National & $<18$ \\
\hline Netherlands & 0.64 & 0.47 & Statute & National & $<23$ \\
\hline New Zealand & 0.57 & 0.46 & Statute & National & $<20$ \\
\hline Canada & 0.52 & 0.43 & Statute & $\begin{array}{l}\text { National, } \\
\text { Provincial }\end{array}$ & No \\
\hline United Kingdom & 0.43 & 0.42 & $\begin{array}{l}\text { Wage } \\
\text { Councils }\end{array}$ & Industry & $<21$ \\
\hline Portugal & 0.48 & 0.38 & Statute & National & $<18$ \\
\hline United States & 0.47 & 0.36 & Statute & $\begin{array}{l}\text { National, } \\
\text { State }\end{array}$ & Limited \\
\hline Japan & 0.29 & 0.33 & Statute & Prefecture & No \\
\hline Spain & 0.48 & 0.32 & Statute & National & $<18$ \\
\hline
\end{tabular}

Notes: Minimum wage ratios are from the OECD minimum wage database and Dolado, et al. (1996). The OECD uses a median wage to calculate the ratios, while Dolado, et al. use a mean wage. Other information is taken from Table 2.1 in OECD (1998), Table 1 in Dolado, et al., and from reports by the European Commission (1998) and the United Kingdom Low Pay Commission (2001). Figures in parentheses refer to the year for which information on minimum wages was available for countries for which we did not have data for 2000 .

1. Figure refers to 1985. 
Table 2

\section{Minimum Wage Levels and Youth Labor Market Conditions}

\begin{tabular}{|c|c|c|c|c|c|c|}
\hline \multirow[b]{2}{*}{ Country } & \multicolumn{2}{|c|}{ Minimum Wage Ratio } & \multicolumn{2}{|c|}{ Employment/Pop. Ratio } & \multicolumn{2}{|c|}{ Unemployment Rate } \\
\hline & 1986 & 2000 & 1986 & 2000 & 1986 & 2000 \\
\hline Italy & 0.75 & -- & 0.29 & 0.26 & 34.5 & 29.7 \\
\hline Norway & -- & -- & 0.62 & 0.58 & 5.0 & 10.2 \\
\hline France & 0.63 & 0.62 & 0.33 & 0.23 & 23.4 & 20.7 \\
\hline Australia & 0.63 & 0.58 & 0.60 & 0.61 & 14.5 & 12.3 \\
\hline Germany & 0.59 & -- & 0.55 & 0.48 & 7.8 & 7.7 \\
\hline Ireland & -- & 0.56 & 0.41 & 0.48 & 25.7 & 6.4 \\
\hline Denmark & 0.62 & -- & 0.69 & 0.67 & 8.1 & 6.7 \\
\hline Finland & -- & -- & 0.54 & 0.40 & 10.1 & 21.6 \\
\hline Greece & 0.59 & 0.51 & 0.30 & 0.27 & 24.2 & 29.5 \\
\hline Sweden & 0.57 & -- & 0.62 & 0.46 & 6.8 & 11.9 \\
\hline Belgium & 0.57 & 0.49 & 0.34 & 0.30 & 21.1 & 15.2 \\
\hline Luxembourg & 0.46 & 0.49 & 0.54 & 0.32 & 6.2 & 6.4 \\
\hline Netherlands & 0.56 & 0.47 & 0.40 & 0.68 & 20.0 & 6.6 \\
\hline New Zealand & 0.47 & 0.46 & 0.67 & 0.55 & 7.8 & 13.2 \\
\hline Canada & 0.39 & 0.42 & 0.59 & 0.56 & 14.8 & 12.6 \\
\hline United Kingdom & 0.46 & 0.42 & 0.63 & 0.62 & 17.9 & 11.8 \\
\hline Portugal & 0.47 & 0.38 & 0.51 & 0.42 & 18.5 & 8.6 \\
\hline United States & 0.37 & 0.36 & 0.60 & 0.60 & 13.3 & 9.3 \\
\hline Japan & 0.29 & 0.33 & 0.41 & 0.43 & 5.2 & 9.2 \\
\hline Spain & 0.37 & 0.32 & 0.31 & 0.36 & 42.8 & 25.5 \\
\hline $\begin{array}{l}\text { Correlation with } \\
\text { minimum wage }\end{array}$ & -- & -- & -0.20 & -0.21 & 0.20 & 0.08 \\
\hline $\begin{array}{l}\text { Correlation with the } \\
\text { change in the } \\
\text { minimum wage }\end{array}$ & -- & -- & -- & $-0.46^{*}$ & -- & $0.50 * *$ \\
\hline
\end{tabular}


Table 3

\section{Estimates of the Standard Minimum Wage Model Using International Data}

\begin{tabular}{|c|c|c|c|c|c|c|}
\hline Variable & $\begin{array}{l}(1) \\
\text { OLS }\end{array}$ & $\begin{array}{l}(2) \\
\mathrm{FE}\end{array}$ & $\begin{array}{l}\text { (3) } \\
\mathrm{FE}\end{array}$ & $\begin{array}{l}\text { (4) } \\
\mathrm{FE}\end{array}$ & $\begin{array}{l}(5) \\
\mathrm{FE}\end{array}$ & $\begin{array}{c}(6) \\
\text { GMM }\end{array}$ \\
\hline \multicolumn{7}{|c|}{ Panel A: Youths (15-24) } \\
\hline Minimum wage ratio (lagged) & $\begin{array}{l}-.21 \\
(.06)\end{array}$ & $\begin{array}{l}-.14 \\
(.08)\end{array}$ & $\begin{array}{l}-.27 \\
(.07)\end{array}$ & $\begin{array}{l}-.17 \\
(.07)\end{array}$ & $\begin{array}{l}-.15 \\
(.07)\end{array}$ & $\begin{array}{l}-.12 \\
(.06)\end{array}$ \\
\hline Lagged employment rate & -- & -- & -- & -- & -- & $\begin{array}{l}.42 \\
(.04)\end{array}$ \\
\hline Adult unemployment rate & $\begin{array}{l}-1.60 \\
(.19)\end{array}$ & $\begin{array}{l}-1.64 \\
(.10)\end{array}$ & $\begin{array}{l}-1.36 \\
(.12)\end{array}$ & $\begin{array}{l}-1.40 \\
(.08)\end{array}$ & $\begin{array}{l}-1.32 \\
(.10)\end{array}$ & $\begin{array}{l}-.86 \\
(.08)\end{array}$ \\
\hline Relative cohort size & $\begin{array}{l}.46 \\
(.12)\end{array}$ & $\begin{array}{l}.35 \\
(.06)\end{array}$ & $\begin{array}{l}-.04 \\
(.07)\end{array}$ & $\begin{array}{l}-.14 \\
(.08)\end{array}$ & $\begin{array}{l}-.26 \\
(.08)\end{array}$ & $\begin{array}{l}-.06 \\
(.06)\end{array}$ \\
\hline $\mathrm{R}^{2}$ & .23 & .58 & .66 & .87 & .89 & -- \\
\hline $\begin{array}{l}\text { Hausman/Sargan test for exclusion } \\
\text { of additional controls ( } p \text {-values) }\end{array}$ & -- & .00 & .00 & .00 & .00 & -- \\
\hline Minimum wage elasticity & -.22 & -.15 & -.28 & -.18 & -.16 & -.13 \\
\hline \multicolumn{7}{|c|}{ Panel B: Teenagers (15-19) } \\
\hline Minimum wage ratio (lagged) & $\begin{array}{l}-.12 \\
(.08)\end{array}$ & $\begin{array}{l}.06 \\
(.10)\end{array}$ & $\begin{array}{l}-.15 \\
(.10)\end{array}$ & $\begin{array}{l}-.20 \\
(.08)\end{array}$ & $\begin{array}{l}-.20 \\
(.08)\end{array}$ & $\begin{array}{l}-.13 \\
(.06)\end{array}$ \\
\hline Lagged employment rate & - & -- & -- & -- & - & $\begin{array}{l}.55 \\
(.04)\end{array}$ \\
\hline Adult unemployment rate & $\begin{array}{l}-1.19 \\
(.26)\end{array}$ & $\begin{array}{l}-1.68 \\
(.14)\end{array}$ & $\begin{array}{l}-1.13 \\
(.15)\end{array}$ & $\begin{array}{l}-1.36 \\
(.11)\end{array}$ & $\begin{array}{l}-1.17 \\
(.13)\end{array}$ & $\begin{array}{l}-.65 \\
(.09)\end{array}$ \\
\hline Relative cohort size & $\begin{array}{c}.82 \\
(.17)\end{array}$ & $\begin{array}{l}.28 \\
(.07)\end{array}$ & $\begin{array}{l}-.26 \\
(.09)\end{array}$ & $\begin{array}{l}-.03 \\
(.10)\end{array}$ & $\begin{array}{l}-.10 \\
(.11)\end{array}$ & $\begin{array}{l}.05 \\
(.07)\end{array}$ \\
\hline $\mathrm{R}^{2}$ & .12 & .41 & .54 & .83 & .85 & -- \\
\hline $\begin{array}{l}\text { Hausman/Sargan test for exclusion } \\
\text { of additional controls ( } p \text {-values) }\end{array}$ & -- & .00 & .00 & .00 & .00 & -- \\
\hline Minimum wage elasticity & -.19 & .09 & -.24 & -.31 & -.24 & -.18 \\
\hline \multicolumn{7}{|c|}{ Controls (both samples) } \\
\hline Country effects & $\mathrm{N}$ & $\mathrm{Y}$ & Y & $\mathrm{Y}$ & Y & Y \\
\hline Year effects & $\mathrm{N}$ & $\mathrm{N}$ & $\mathrm{Y}$ & $\mathrm{N}$ & $\mathrm{Y}$ & Y \\
\hline Time trends & $\mathrm{N}$ & $\mathrm{N}$ & $\mathrm{N}$ & $\mathrm{Y}$ & $\mathrm{Y}$ & Y \\
\hline
\end{tabular}

Notes: The dependent variable is the employment-to-population ratio for the age group indicated. Standard errors are shown in parentheses. The sample period is from 1976 to 2000, except for the following countries: Germany (1976-1994), Italy (1976-1991), Sweden (1976-1992), U.K. (1984-1992), New Zealand (1986-2000), Belgium (1983-2000), Luxembourg (1983-2000), Greece (1983-2000), Denmark (1983-1994), and Australia (1985-2000). The sample includes all of the countries listed in Table 1 except Norway, Finland, and Ireland. 
Table 4

Differences in Minimum Wage Effects by Other Characteristics of Minimum Wage Systems

\begin{tabular}{|c|c|c|c|c|c|c|}
\hline \multirow[b]{2}{*}{ Variable } & \multicolumn{3}{|c|}{ Youths } & \multicolumn{3}{|c|}{ Teenagers } \\
\hline & $\begin{array}{l}(1) \\
\text { OLS } \\
\end{array}$ & $\begin{array}{l}(2) \\
\mathrm{FE}\end{array}$ & $\begin{array}{c}(3) \\
\text { GMM } \\
\end{array}$ & $\begin{array}{c}(4) \\
\text { OLS }\end{array}$ & $\begin{array}{l}(5) \\
\mathrm{FE}\end{array}$ & $\begin{array}{c}(6) \\
\text { GMM } \\
\end{array}$ \\
\hline Minimum wage ratio & $\begin{array}{l}-.33 \\
(.07)\end{array}$ & $\begin{array}{l}-.10 \\
(.18)\end{array}$ & $\begin{array}{l}-.04 \\
(.14)\end{array}$ & $\begin{array}{l}.03 \\
(.09)\end{array}$ & $\begin{array}{l}-.36 \\
(.21)\end{array}$ & $\begin{array}{l}-.14 \\
(.15)\end{array}$ \\
\hline \multicolumn{7}{|l|}{ Dummy variables: } \\
\hline Bargained minimum & $\begin{array}{l}.03 \\
(.03)\end{array}$ & -- & -- & $\begin{array}{l}-.04 \\
(.03)\end{array}$ & -- & -- \\
\hline Subnational minimum rates & $\begin{array}{l}.06 \\
(.02)\end{array}$ & -- & -- & $\begin{array}{l}.13 \\
(.03)\end{array}$ & -- & -- \\
\hline Youth subminimum & $\begin{array}{l}.13 \\
(.02)\end{array}$ & -- & -- & $\begin{array}{l}.27 \\
(.02)\end{array}$ & -- & -- \\
\hline \multicolumn{7}{|l|}{ Interaction with minimum wage: } \\
\hline Bargained minimum & -- & $\begin{array}{l}.28 \\
(.25)\end{array}$ & $\begin{array}{l}.31 \\
(.19)\end{array}$ & -- & $\begin{array}{l}.05 \\
(.31)\end{array}$ & $\begin{array}{l}.10 \\
(.21)\end{array}$ \\
\hline Subnational minimum rates & -- & $\begin{array}{l}-.34 \\
(.21)\end{array}$ & $\begin{array}{l}-.29 \\
(.17)\end{array}$ & -- & $\begin{array}{l}-.17 \\
(.26)\end{array}$ & $\begin{array}{l}-.18 \\
(.19)\end{array}$ \\
\hline Youth subminimum & -- & $\begin{array}{c}.43 \\
(.20)\end{array}$ & $\begin{array}{c}.09 \\
(.16)\end{array}$ & -- & $\begin{array}{c}.90 \\
(.25)\end{array}$ & $\begin{array}{c}.30 \\
(.18)\end{array}$ \\
\hline $\begin{array}{l}\text { Hausman/Sargan test for country } \\
\text { effects ( } p \text {-values) }\end{array}$ & .00 & -- & -- & .00 & -- & -- \\
\hline Controls: & & & & & & \\
\hline Country effects & $\mathrm{N}$ & $\mathrm{Y}$ & $\mathrm{Y}$ & $\mathrm{N}$ & $\mathrm{Y}$ & $\mathrm{Y}$ \\
\hline Year effects & $\mathrm{Y}$ & Y & Y & Y & Y & Y \\
\hline Time trends & Y & Y & $\mathrm{Y}$ & $\mathrm{Y}$ & Y & Y \\
\hline
\end{tabular}

Notes: See notes to Table 3. "Bargained minimum" refers to countries in Table 2 for which minimum wages are not set by statute. "Youth Subminimum" refers to countries with a specified age (in Table 2) for the applicability of a subminimum, and excludes countries with limited subminimums. Each specification also includes the adult unemployment rate and the relative cohort size variable. 
Table 5

Other Labor Market Policies and Institutions

\begin{tabular}{lccccc}
\hline Country & $\begin{array}{c}\text { Labor } \\
\text { Standards }\end{array}$ & $\begin{array}{c}\text { Employment } \\
\text { Protection }\end{array}$ & $\begin{array}{c}\text { Active } \\
\text { Policies }\end{array}$ & $\begin{array}{c}\text { Union } \\
\text { coverage }\end{array}$ & $\begin{array}{c}\text { Unemp. } \\
\text { Insurance }\end{array}$ \\
\hline Italy & 3 & 14.25 & 0.93 & 43.0 & 7.3 \\
Norway & 4 & 9.75 & 1.35 & 54.9 & 34.3 \\
France & 4 & 9.50 & 1.17 & 13.6 & 33.9 \\
Australia & 3 & 3.26 & 0.73 & 44.2 & 25.0 \\
Germany & 4 & 12.00 & 1.33 & 32.0 & 32.0 \\
Ireland & 2 & 2.75 & 1.48 & 54.0 & 28.9 \\
Denmark & 2 & 3.25 & 2.32 & 77.0 & 57.1 \\
Finland & 3 & 10.50 & 1.55 & 72.6 & 33.5 \\
Greece & 4 & 11.00 & 0.36 & 28.6 & 13.5 \\
Sweden & 5 & 8.50 & 3.00 & 83.6 & 27.4 \\
Belgium & 2 & 10.50 & 1.39 & 52.4 & 42.3 \\
Luxembourg & -- & -- & 0.26 & -- & - \\
Netherlands & 4 & 7.25 & 1.06 & 27.9 & 49.0 \\
New Zealand & 3 & 0.72 & 0.69 & 33.6 & 29.2 \\
Canada & 1 & 1.65 & 0.56 & 36.7 & 28.3 \\
United Kingdom & 0 & 2.25 & 0.53 & 46.0 & 20.2 \\
Portugal & 2 & 12.50 & 0.73 & 45.3 & 24.1 \\
United States & 0 & 0.36 & 0.20 & 18.3 & 12.7 \\
Japan & 1 & 3.71 & 0.11 & 25.4 & 9.8 \\
Spain & 3 & 11.25 & 0.72 & 13.6 & 30.1 \\
& & & & & \\
Correlation with & $0.57^{* *}$ & $0.38 *$ & $0.36 *$ & 0.29 & 0.23 \\
minimum wage & & & & & \\
\hline Notes: Union & & & & & \\
\end{tabular}

Notes: Union coverage refers to the number of total union members as a percent of wage and salary employee and is taken from Nickell and Nunziata (2001). The measure of unemployment insurance shown here is the average gross benefit replacement rate (as a percent of earnings) as defined by the OECD (1994); the figures refer to the mean replacement rate from the 1976-1997. The labor standards index, which refers to 1993 standards, is taken from OECD (1994) and excludes the contributions of minimum wages and employment protection policies to the index. The employment protection index is taken from OECD (1996) and refers to legislation as of 1989. The active labor market policies index is taken from OECD (1996) and is measured as public expenditures on public employment services, labor market training, and subsidized employment measures in fiscal year 1995 as a percent of GDP. ** indicates statistical significance at the 5\% level, while * indicates significance at the $10 \%$ level. 
Table 6

Differences in Minimum Wage Effects by Other Labor Market Policies and Institutions

\begin{tabular}{|c|c|c|c|c|c|c|}
\hline \multirow[b]{2}{*}{ Variable } & \multicolumn{3}{|c|}{ Youths } & \multicolumn{3}{|c|}{ Teenagers } \\
\hline & $\begin{array}{l}(1) \\
\text { OLS }\end{array}$ & $\begin{array}{l}(2) \\
\mathrm{FE}\end{array}$ & $\begin{array}{c}(3) \\
\text { GMM }\end{array}$ & $\begin{array}{l}(4) \\
\text { OLS }\end{array}$ & $\begin{array}{l}(5) \\
\text { FE }\end{array}$ & $\begin{array}{c}(6) \\
\text { GMM }\end{array}$ \\
\hline Minimum wage ratio & $\begin{array}{l}-.30 \\
(.05)\end{array}$ & $\begin{array}{l}-.12 \\
(.08)\end{array}$ & $\begin{array}{l}-.08 \\
(.06)\end{array}$ & $\begin{array}{l}-.39 \\
(.08)\end{array}$ & $\begin{array}{l}-.14 \\
(.10)\end{array}$ & $\begin{array}{l}-.15 \\
(.06)\end{array}$ \\
\hline $\begin{array}{l}\text { Coefficient on: } \\
\text { Labor standards index }\end{array}$ & $\begin{array}{l}-.12 \\
(.02)\end{array}$ & -- & -- & $\begin{array}{l}-.03 \\
(.05)\end{array}$ & -- & -- \\
\hline $\begin{array}{l}\text { Employment protection } \\
\text { index }\end{array}$ & $\begin{array}{l}.05 \\
(.02)\end{array}$ & -- & -- & $\begin{array}{l}.08 \\
(.03)\end{array}$ & -- & -- \\
\hline $\begin{array}{l}\text { Active labor market } \\
\text { policies }\end{array}$ & $\begin{array}{l}.22 \\
(.02)\end{array}$ & -- & -- & $\begin{array}{l}.13 \\
(.04)\end{array}$ & -- & -- \\
\hline UI replacement rate & $\begin{array}{l}-.08 \\
(.01)\end{array}$ & $\begin{array}{l}-.02 \\
(.01)\end{array}$ & $\begin{array}{l}-.01 \\
(.01)\end{array}$ & $\begin{array}{l}-.10 \\
(.03)\end{array}$ & $\begin{array}{c}.01 \\
(.02)\end{array}$ & $\begin{array}{l}.01 \\
(.01)\end{array}$ \\
\hline Union density & $\begin{array}{c}.01 \\
(.01)\end{array}$ & $\begin{array}{l}-.02 \\
(.02)\end{array}$ & $\begin{array}{l}-.02 \\
(.01)\end{array}$ & $\begin{array}{l}.07 \\
(.02)\end{array}$ & $\begin{array}{c}.02 \\
(.02)\end{array}$ & $\begin{array}{l}.02 \\
(.01)\end{array}$ \\
\hline $\begin{array}{l}\text { Interaction with: } \\
\text { Labor standards index }\end{array}$ & -- & $\begin{array}{l}-.16 \\
(.19)\end{array}$ & $\begin{array}{l}-.08 \\
(.13)\end{array}$ & -- & $\begin{array}{l}-.32 \\
(.25)\end{array}$ & $\begin{array}{l}-.24 \\
(.12)\end{array}$ \\
\hline $\begin{array}{l}\text { Employment protection } \\
\text { index }\end{array}$ & -- & $\begin{array}{l}.24 \\
(.13)\end{array}$ & $\begin{array}{l}.21 \\
(.09)\end{array}$ & -- & $\begin{array}{l}.44 \\
(.16)\end{array}$ & $\begin{array}{l}.19 \\
(.09)\end{array}$ \\
\hline $\begin{array}{l}\text { Active labor market } \\
\text { policies }\end{array}$ & -- & $\begin{array}{l}.50 \\
(.15)\end{array}$ & $\begin{array}{l}.12 \\
(.10)\end{array}$ & -- & $\begin{array}{c}.47 \\
(.18)\end{array}$ & $\begin{array}{l}.24 \\
(.10)\end{array}$ \\
\hline UI replacement rate & -- & $\begin{array}{l}-.04 \\
(.06)\end{array}$ & $\begin{array}{l}.05 \\
(.04)\end{array}$ & -- & $\begin{array}{l}-.11 \\
(.08)\end{array}$ & $\begin{array}{l}.03 \\
(.04)\end{array}$ \\
\hline Union density & -- & $\begin{array}{l}-.30 \\
(.07)\end{array}$ & $\begin{array}{l}-.06 \\
(.05)\end{array}$ & -- & $\begin{array}{l}-.24 \\
(.09)\end{array}$ & $\begin{array}{l}-.04 \\
(.05)\end{array}$ \\
\hline $\begin{array}{l}\text { Hausman/Sargan test } \\
\text { for country effects (p- } \\
\text { value) }\end{array}$ & .00 & -- & -- & .00 & -- & -- \\
\hline $\begin{array}{l}\text { Controls: } \\
\text { Country effects } \\
\text { Time trends } \\
\text { Year effects }\end{array}$ & $\begin{array}{l}\mathrm{N} \\
\mathrm{Y} \\
\mathrm{Y}\end{array}$ & $\begin{array}{l}\mathrm{Y} \\
\mathrm{Y} \\
\mathrm{Y}\end{array}$ & $\begin{array}{l}\mathrm{Y} \\
\mathrm{Y} \\
\mathrm{Y}\end{array}$ & $\begin{array}{l}\mathrm{N} \\
\mathrm{Y} \\
\mathrm{Y}\end{array}$ & $\begin{array}{l}\mathrm{Y} \\
\mathrm{Y} \\
\mathrm{Y}\end{array}$ & $\begin{array}{l}\mathrm{Y} \\
\mathrm{Y} \\
\mathrm{Y}\end{array}$ \\
\hline
\end{tabular}

Notes: The policy variables were first standardized (differenced from their means and divided by their standard deviations) to facilitate comparisons. Each specification also includes the adult unemployment rate and the relative cohort size variable. 
Table 7

\section{Minimum Wage Effects Differentiated by Degree of Labor Market Regulation}

\begin{tabular}{|c|c|c|c|c|c|c|c|}
\hline & & \multicolumn{6}{|c|}{ Employment protection/active labor market policies } \\
\hline & \multirow{9}{*}{ High } & \multicolumn{3}{|l|}{ High } & \multicolumn{3}{|c|}{ Low } \\
\hline \multirow{15}{*}{$\begin{array}{l}\text { Labor } \\
\text { standards }\end{array}$} & & & Youth & Teen & & Youth & Teen \\
\hline & & Germany $(2,2)$ & .10 & $\overline{-.10}$ & Netherlands $(2$, & -.16 &.$- \overline{39 * *}$ \\
\hline & & Italy $(5,3)$ & .20 & .04 & Greece $(2,11)$ & -.09 & $-.45^{* *}$ \\
\hline & & Sweden $(1,1)$ & .15 & .12 & Australia $(5,12)$ & $-.34 * *$ & $-.49 * *$ \\
\hline & & Spain $(5,8)$ & .03 & -.16 & NZ $(5,9)$ & -.21 & -.09 \\
\hline & & France $(5,7)$ & .02 & -.09 & & & \\
\hline & & $\begin{array}{l}\text { Average effect: } \\
\text { Implied }\end{array}$ & .09 & -.05 & $\begin{array}{l}\text { Average effect: } \\
\text { Implied }\end{array}$ & -.19 & $-.36^{* *}$ \\
\hline & & Estimated & $.27 * *$ & .11 & Estimated & -.01 & $-48 * *$ \\
\hline & Low & & Youth & Teen & & Youth & Teen \\
\hline & & Belgium $(10,4)$ & .16 & .19 & U.S. $(15,16)$ & $-.38 * *$ & $-.27 * *$ \\
\hline & & Portugal $(10,6)$ & .15 & .07 & U.K. $(15,13)$ & $-.25 * *$ & -.09 \\
\hline & & Denmark $(10,5)$ & -.03 & .19 & Canada $(13,14)$ & $-.33 * *$ & $-.27 * *$ \\
\hline & & & & & Japan $(13,15)$ & $-.30 * *$ & $-.32 * *$ \\
\hline & & $\begin{array}{l}\text { Average effect: } \\
\text { Implied }\end{array}$ & .11 & .14 & $\begin{array}{l}\text { Average effect: } \\
\text { Implied }\end{array}$ & $-.33 * *$ & $-.27 * *$ \\
\hline & & Estimated & .07 & .15 & Estimated & $-.43 * *$ & $-.33 * *$ \\
\hline
\end{tabular}

Notes: The pairs of numbers after each country are ranks, based on Table 5, for the labor standards index and the average of the standardized employment protection and active labor market policies indices. The minimum wage effects for each country are based on the indicated specifications in Table 6, columns (3) and (6); they are calculated as the coefficient on the minimum wage variable, plus each of the coefficients on the interaction terms multiplied by the standardized value of the policy variable for that country. The implied average effect is based on the same calculation, but using the average values of the policy variables for the set of countries in the indicated cell. The estimated effects for each panel are based on estimates of the model using the full sample but allowing the minimum wage coefficient to differ for the four different panels. ** indicates statistical significance at the $5 \%$ level, while * indicates significance at the $10 \%$ level. 